\title{
An Overview of the Homeschooling Landscape
}

Homeschooling in its various forms is, without question, the oldest form of semi-formal education throughout all of the history of humanity. Adults have been teaching their children for thousands of years all manner of survival knowledge dating back to early humans such as hunting, gathering, and defense from predators to agricultural knowledge with the advent of the agricultural revolution in Mesopotamia. I refer to this as semi-formal rather than formal education in the sense that such training and skills transfer was done not only as an imperative for survival but often done so in the action of addressing immediate needs and not, necessarily, done in a structured environment (structured homeschooling or otherwise). That is, this teaching and learning was not understood as a formalized process where specific time, goals, and agendas were targeted and met. The teaching here falls along the normal teaching that parents do in the daily efforts to socialize their children into the norms of a particular family, language, culture, geographic region, etc. The historical and legal basis for homeschooling in the United States rests in the Supreme Court decisions of Meyer v. Nebraska (1926) and Pierce v. Society of Sisters (1925). Those cases concluded that "the state does not have the power to 'standardize its children by forcing them to accept instruction from public teachers only"' (Kunzman, 2012, p. 77) and that parents have a natural - though, not constitutional - right to decide the type of education their children receive. This lack of an explicit constitutional right is at odds with the prevailing assertion following these cases that the natural rights of the parent (or parental sovereignty) supersede the need of such legal rights. Specifically, while the U.S. Constitution does not explicitly afford children the right to an education (though, most state Constitutions do as does the United Nation's Declaration of Human Rights) and all states require compulsory attendance at some type of schooling (by and large, public schools), the ascendancy of parental sovereignty over such laws continues to establish the conception of parental control as not only natural but above some conceptions of international, federal, and state laws. This is not exclusive to homeschooling as many states allow parents to opt-out of legally mandated vaccination schedules sometimes on a whim following the development of ideology suspicious of vaccines after viewing YouTube videos of celebrities who are champions of the anti-vaccination movement. And while my intent here is not to challenge the role that parents do, and should, play in the lives of their children, the 
question becomes to what extent do individual choices made to benefit individual children (whether those choices are good or negligent) impact those children themselves and others in both the immediate sense but in a long-term societal sense.

Here, then, it becomes necessary to question role of homeschooling in the United States in terms of where the line is, should be (or should not be), drawn between semi-formal socialization overseen by parents and more formal education delivered and administrated by professionals, overseen by the state (the formal collective voice of society). At odds here is an overarching debate about the role of parental sovereignty and striking a balance between such sovereignty (a decidedly individual approach and administration of socialization) and each family's broader commitment and obligation to the common good and the function of the common good (the public/state) to help ensure the transmission of its own civic culture and ensuring that children are being provided an ample opportunity towards adulthood that naturally follows appropriate educational and growth development.

Generally speaking, there are two overarching rationales for why parents will chose to homeschool their children. And while my intention here is not to fit all parents into a box or generalize, it is worth categorizing rationales so that a discussion and assessment can follow. There are two broad categories that can explain rationales to homeschool: "(1) empirical - claims of greater efficiency, effectiveness, or pedagogical appropriateness; and (2) ideological often informed by a religious or political disposition" (Brewer \& Lubienski, 2017, p. 22). Each of these two broad categorizations of rationales can be subdivided into underlying assumptions, dispositions, and ideologies about curriculum, student development, assessment strategies, individualized instruction, addressing students with disabilities, beliefs about the broader culture in society, thoughts of bullying and other issues related to real or perceived threats to safety, beliefs about the role of science in relation to religion (e.g., creationism versus evolution), stances on sex education, political beliefs about the role of government in schools, indoctrination, and conspiracy theories that can, at times, provide an intersection for political and religious beliefs - quite often becoming dangerous (Westover, 2018).

In its 2012 survey, the Department of Education found that "nine in 10 homeschooled students' parents reported that concern about schools' environments was an important reason for their decision to homeschool" 


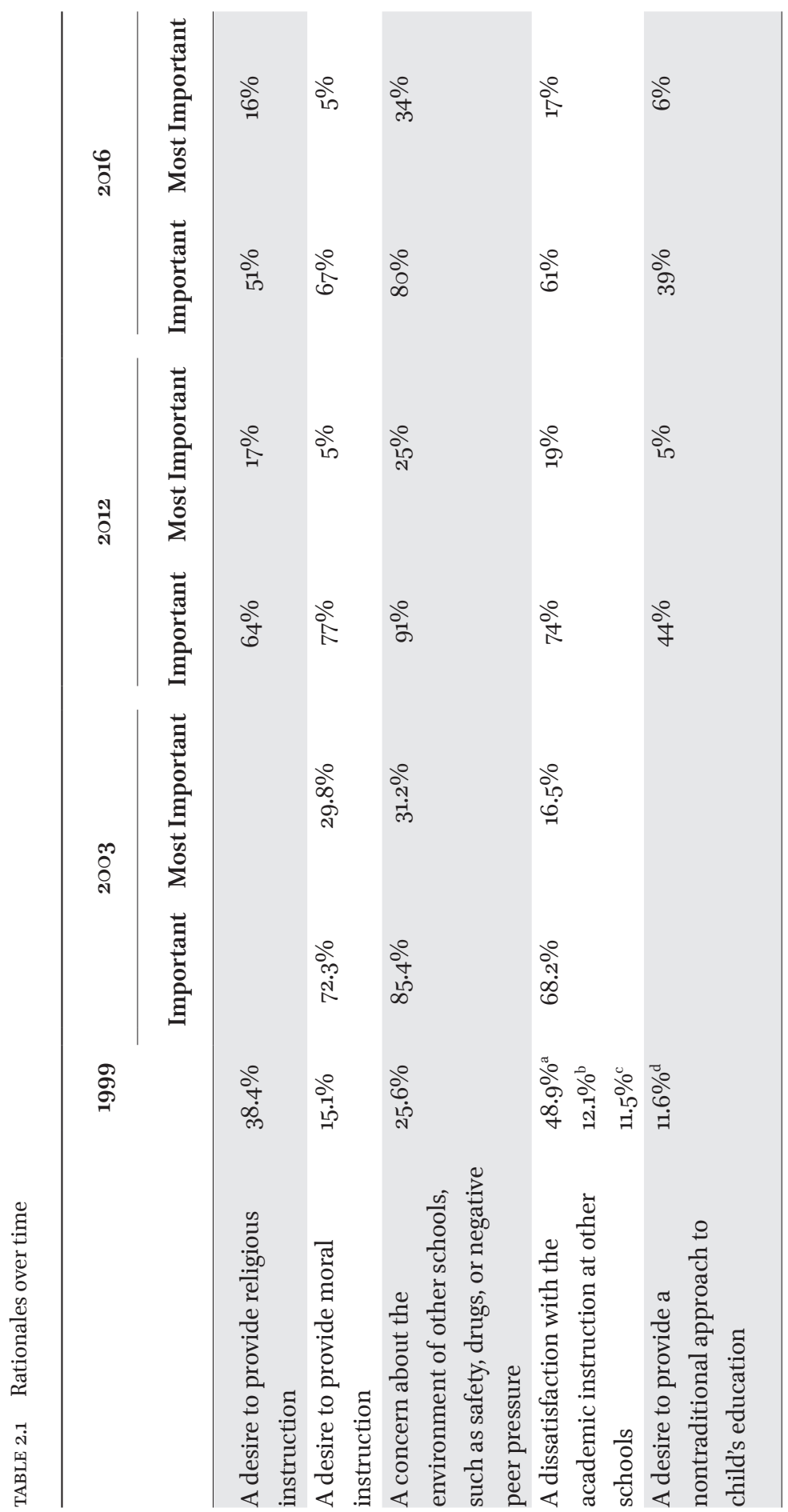




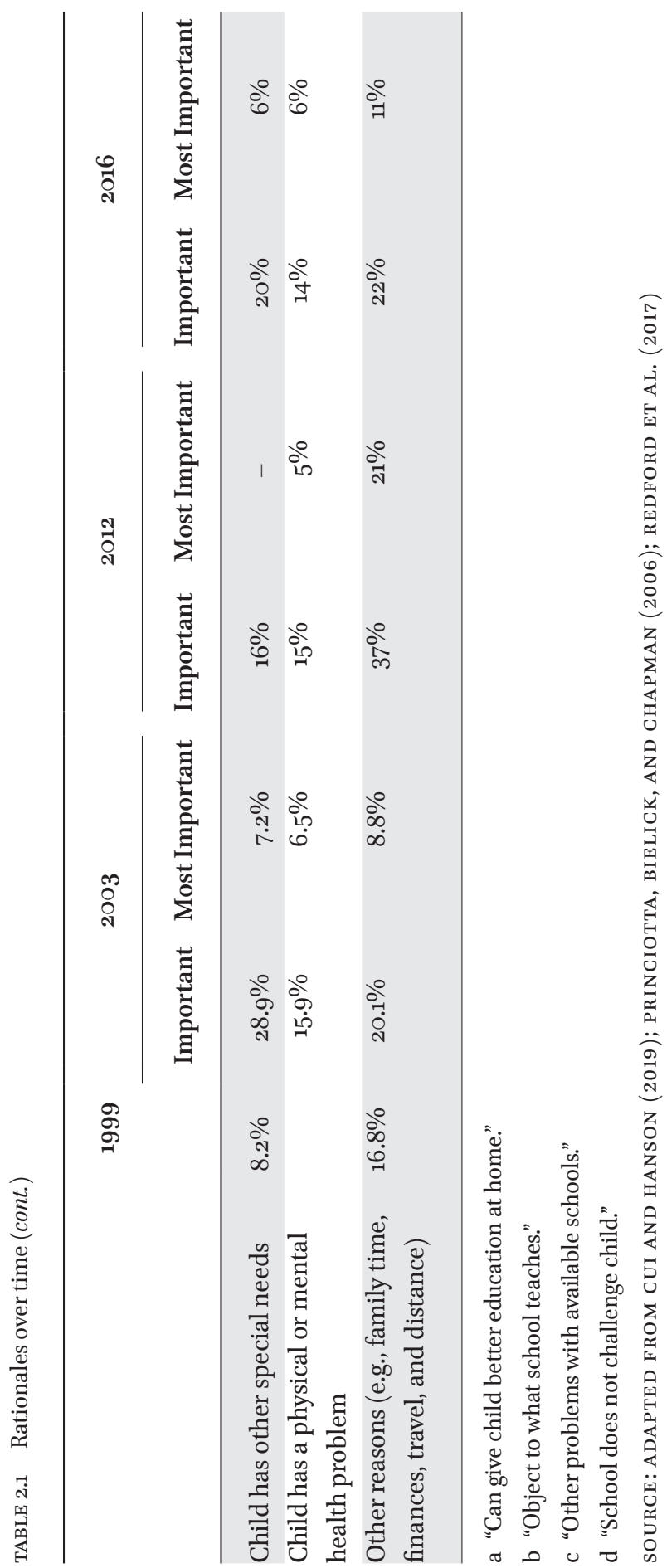


(Redford, Battle, Bielick, \& Grady, 2017, p. 11). Table 2.1 represents a compilation of statistics related to parental rationales to homeschool over time. In the surveys conducted by the National Center for Education Statistics (NCES) (where the data in Table 2.1 is derived from), parents could select one or more rationales.

As explicated in Table 2.1, the largest rationale provided as the "most important" reason for choosing to homeschool is "a concern about the environment of schools." While "a desire to provide religious instruction" is among the highest rationales reported, it is not unreasonable to assume that many of the rationales related to concerns about school environments or "dissatisfaction with the academic instruction" are, perhaps, informed by religious doctrine as homeschooling is seen by some as "one of the last opportunities to teach our children the unpolluted truth. If the public schools continue down their current path, Christians, conservatives and those who simply fear for their child's safety are going to start withdrawing their children" (Schillinger, Ray, Knapp, \& Newman, n.d.).

Before we explore more specific claims about the negative influences of public education that are often promoted to support the growth of homeschooling, a brief aside as a way to provide context for how these claims take on a life of their own. In the 1962 film The Music Man, a seminal scene depicts the intentional and viral development of a myth and fear mongering surrounding the installation of a new billiards table in the local pool hall. Harold Hill (played by Robert Preston) notes the need to "create a problem," and "create a need" for his boy choir by creating and perpetuating myths surrounding how the game of billiards would result in the moral decay of the children in River City, the townspeople quickly adopt the belief that the new billiards table and the pool hall represent an existential threat to children. Lubienski and Lubienski (2014) also noted The Music Man as an example of expressing precisely how motivations to change are often prompted once people feel that trouble exists all around them. Lubienski and Lubienski go on to argue that the manufacturing of a perception of trouble is precisely what Milton Friedman had in mind when he suggested that "only a crisis - actual or perceived - produces real change" (Lubienski \& Lubienski, 2014, p. 4) which is a disposition towards disaster capitalism as explored by Naomi Klein (2007), embodied by Secretary of Education Arne Duncan's push to replace public schools with charter schools in New Orleans after Hurricane Katrina, and aligns with the broader and decades long manufacturing of a perception of crises in an effort to undermine public education in favor of private options (Berliner \& Biddle, 1995; Berliner \& Glass, 2014; deMarrais, Brewer, Atkinson, Herron, \& Lewis, 2019; Kumashiro, 2012; MacLean, 2017). 
When it comes to choosing homeschooling over public education due to the perceived threats that have been manufactured by pro-reform individuals, families, and organizations, the creation and perpetuation of rhetoric that is presented not only as commonsensical but laden with what appear to be statistics reinforces parental concerns about the safety of children and the learning environments at public schools. And this perceived fear is not limited to the United States as concerns about the environment of local schools in Indonesia, as one example, also frequently cite school environments, child safety concerns, special needs of children, and "disagreement" with the government curriculum (Baidi, 2019).

In discussing a newsletter published by Basic Christian Education, Stevens (2001) notes that an article entitled The Basic Educator,

enumerates a score of problems that apparently are pervasive in American classrooms. The list covers a wide swath: " 50 percent of the girls will become pregnant out of wedlock before graduation day. 70 percent of the boys will become sexually active before they leave high school;" children will be "exposed to violence, crime, lack of discipline, and, of course, drugs of every kind;" "Communism and socialism may be presented in the best possible light and capitalism taught as a greed-motivated economic system;" "Many [children] will be exposed to New Age philosophies, Yoga, Transcendental Meditation, witchcraft demonstrations, and Eastern religions." (p. 51)

Tedious as it may be, it is worthwhile to explore each of these typical claims each in turn as parental concern surrounding the environment of public schools is consistently one of the most cited justifications for homeschooling (see Table 2.1).

First, it is important to point out that according to the Centers for Disease Control (CDC) and the U.S. Department of Health \& Human Services (HHS), teen pregnancies have been on the decline for decades across the nation (CDC, n.d.; HHS, n.d.). That said, the rate of teen pregnancy is approximately 18.8 per 1,000 women of the ages between 15-19 (CDC, n.d.). Simple mathematical calculation shows that only $1.88 \%$ of girls become pregnant prior to (and even a year after) the traditional graduation age of 18 . The reality that only $1.88 \%$ of girls become pregnant before the age of 20 is a far cry from the fear-mongering statistic suggesting that half of all girls $(50 \%)$ become pregnant as suggested above. The highest recorded rates of teen pregnancies occurred during the 195 os and 196 os where the rate was 96.3 per 1,00o women or $9.63 \%$ of women between the ages of 15-19 (Livingston \& Thomas, 2019). That is, teen pregnancy 
has never in the history of our nation come close to $50 \%$ despite the claims of religious fundamentalists. What is interesting, however, is that while religion is used as a justification for avoidance of what is seen as sexual promiscuity and actions that lead to teen pregnancy, teen pregnancy rates are highest in states "whose residents have more conservative religious beliefs" (Jenna, 2009) or colloquially known as the "Bible Belt" due to a avoidance of sex-education, use of and discussions surrounding contraceptives, and the employment of an "abstinence-only" approach to sex (Grady-Pawl, 2017). Additionally, states within the Bible Belt also have rates of teen STDs so high that they are "high enough to be classified as epidemic" (Bushak, 2014).

What is not discernable from the fear-mongering statistic suggesting that $70 \%$ of boys become sexually active is how the religious publication defines sexual activity. Despite the unsupported claim that $70 \%$ of boys become sexually active before they leave high school, the CDC notes that $44 \%$ of teen males have had sex and $42 \%$ of females have had sex between the ages of $15^{-19}$ (CDC, 2017).

As noted above, sex education is often a topic scorned by many among the religious right. Believing that educating children about sex, safe sex, sexually transmitted diseases, etc. has long been argued as resulting in the encouragement to teenagers to engage in sexual activities. And despite the data explicated above concluding that states that have sex education have better health outcomes than those states who rely on abstinence-only approaches, the myth of a connection between sex education and promiscuity continues to rely on false information. Katherine Stewart (Stewart, 2019) documented how evangelical religious right leaders produce fliers with intentionally misleading information to flame fear about sex education in public schools by using graphic sexual photos that are either not used at all in the curriculum or some of the less graphic ones being labeled as being used at the elementary level when they are, in fact, used at the high school level. Further, Metzel notes that an increase in health-related instruction is likely associated with better longterm health outcomes including, but not limited to, mortality rates (Metzl, 2019). And this makes sense given that states who have either employed an approach of ignoring sex education or using an abstinence-only approach to what is decidedly a healthcare issue, has resulted in higher rates of teen pregnancies and STD transmissions. To put it bluntly, those states where students attend schools with limited (abstinence only) or no exposure to sex education are far more likely to experience teen pregnancy and STDs. As is the case of many religious doctrines, abstinence and virginity are paramount characteristics of what is considered 'holy' and 'pure' for children and young adults pre-marriage. In fact, some fundamentalist Evangelical Christians go as far as holding "purity balls" where a virgin daughter and her father spend the evening 
dancing while the daughter pledges to remain celibate and "married" to her father until she is actually married (Frank, 2017) as a manifestation of how religious views can shape and inform cultural beliefs.

The claim that attendance at a public school, rather than homeschooling, will expose children to violence, crime, lack of discipline, and drugs has long been a scare tactic. The juxtaposition of public schools as an environment of drugs, alcohol, and violence to the pristine environment of homeschooling has, as explicated in the suggestion above, been a driving fear tactic. In an article published in 2017, we included a notable political cartoon that depicted, on the left side, a downtrodden student with a cigarette in his mouth and hand on a gun above the phrase "public school has so much to offer..." while the right side of the cartoon depicts a smiling boy with his hands posed on a book above the phrase "not like Christian homeschooling!" (Brewer \& Lubienski, 2017). The cartoon is meant as tongue-in-cheek sarcasm attempting to illustrate that attendance at a public school will, despite the sarcasm, result in students smoking and using guns while engaging in Christian homeschooling will result in happiness and wholesomeness. Again, playing into the fear mongering narrative that public schools have little to offer other than deviance and amorality.

While there has, seemingly, been an increase in gun-related violence on school campuses in the form of shootings and mass shootings, children are far more likely to have regular exposure to firearms at home. In fact, 1 out of 3 homes in the United States with kids have guns in the home - of which 1.7 million children live in homes where guns are kept unlocked and loaded (Children's Hospital of Philadephia Researach Institute, n.d.). Further, $89 \%$ of all children killed as a result of unintentional guns use occurs in the home while children are "playing with a loaded gun in their parent's absence" (Children's Hospital of Philadephia Researach Institute, n.d.). Moreover, gun ownership at home is connected to an increased risk of dying at home as a result of gun-related homicide or suicide (Dahlberg, Ikeda, \& Kresnow, 2004; Metzl, 2019). I want to be clear here, I am not suggesting that if $\mathrm{A}+\mathrm{B}=\mathrm{C}$ then $\mathrm{C}+\mathrm{B}$ should equal $\mathrm{A}$. That is, I am not suggesting that because students are more likely to be injured or killed at home by firearms that the practice of homeschooling would, or does, lead to more firearm deaths. What I am pointing out, however, is the logical fallacy in the argument that it is public schools, as a practice, that brings students into more prevalent contact with guns and, therefore, gun violence as suggested by such cartoons as the one explicated above when children are far more likely to be injured or killed by firearms at home - which happens for all children regardless of whether they are homeschooled or attend public schools. Yet, it does seem to follow that the homeschooling movement - which is largely a movement to deregulate and dismantle public oversight - generally 
might fall into gun ownership culture. So much so that the HSLDA fought to prevent homeschools from being regulated as gun-free zones (like their public school counterparts) as it represented a "[threat] to home schooling freedoms everywhere" (A2Z Homeschooling, n.d.).

Outside of the perception that public schools expose children to gun violence, there is yet another overlooked reality surrounding violence towards children that many homeschooling advocates ignore: abuse and neglect. The website Homeschooling's Invisible Children offers a searchable national database of instances of child abuse, neglect, and child deaths as a result of abuse and neglect. The site is affiliated with the Coalition for Responsible Home Education (CRHE). A simple search of the CRHE site (CRHE, n.d.-b) for the word "abuse" returns stores with the following phrases or words in the headlines: "verbal and physical abuse was a norm," "homeschooling used to hide abuse," "exploitation," "abuse and torture," "physical abuse and neglect was obvious to me" "children imprisoned" just to name a few. Every year there are national headlines of parents abusing the homeschooling laws to imprison, abuse, exploit, and kill children. Often, these crimes go unnoticed or unknown for long periods of time due to the lack of public oversight in the practice of homeschooling itself but also the lack of having children exposed to adults other than their abusers. Child abuse occurs no matter the type of schooling children are exposed to. But it is the very nature of public engagement through public schools that offers the opportunity for other adults to observe the signs of abuse and work towards ending the abuse. The very nature of homeschooling, while not synonymous with abuse, creates the possibility that those that are abused may go unnoticed until it is too late.

Citing a study published by the Connecticut Office of the Child Advocate, the CRHE reports that a third of all children pulled out of local public schools in order to homeschool in Connecticut did so "after a Department of Child and Family Services (DCF) investigation revealed they were abusing the child(ren)" (Pollack, 2018). Further, "Instead of stopping or slowing down the abuse, the parent(s) instead figured out a way to continue the abuse, and to even escalate the abuse to torture or homicide without being found out: homeschooling. When parents with a prior abuse history pull their children out of school to 'homeschool' them, this needs to be understood as an escalation and cover up of their criminal activity" (Pollack, 2018). The Homeschooling's Invisible Children database operated by CRHE contends that,

preliminary research suggests that homeschooled children are at a greater risk of dying from child abuse than are traditionally schooled children. This preliminary finding is based on an analysis of the cases in 
our Homeschooling's Invisible Children (HIC) database and on national government reports on child maltreatment. When we compare the rate of child abuse fatalities among homeschooled families to the rate of child abuse fatalities overall, we see a higher rate of death due to abuse or neglect among homeschooled students than we do among children of the same age overall. (Children, n.d.)

This reality is not difficult to understand given that cases of abuse are often uncovered by public school teachers and counselors who come in contact with students on a daily basis. As state mandated reporters, suspicion of abuse or neglect are reported to the proper authorities within 24 hours. Students who are homeschooled are more likely to not come into contact with adults outside of family members or with individuals who have a legal mandate to report suspicious activity or signs of abuse that can lead to short or long term trauma and/ or death. And, as noted in Chapter 1, the national shuttering of public schools for temporary schooling-at-home measures in response to the CoviD-19 pandemic saw a dramatic decrease in the number of abuse cases being reported (Prabhu, 2020). This raises some significant questions about how to regulate the normal traditional practice of homeschooling to ensure that abuse and neglect are not going unnoticed. To that end, following the unreported death of a homeschooled child, the Coalition for Responsible Home Education has advocated for a change to Florida law to include a required in-person check-in with the homeschooling family from a certified teacher each school year (Rozyla, 2015).

Turning back to the other claims above that include claims that "Communism and socialism may be presented in the best possible light and capitalism taught as a greed-motivated economic system;" finds that this claim is not exclusive to the homeschooling community. Indeed, as the Red Scare led to McCarthyism in the 1950s, teachers and public schools became a target for their supposedly anti-American, anti-Capitalism, pro-Communism stance. Teachers were required to sign loyalty pledges denouncing communism out of threat of losing their jobs (Goldstein, 2014). But paranoia about public schools promoting socialism and communism over capitalism did not end with the end of McCarthyism. Organizations such as TurningPoint USA with close ties to the Trump administration have long pushed the claim that K-12 schools and college campuses are a breeding ground for communism and socialism in addition to the denigration of capitalism. One of the most notable educational pamphlets published by TPUSA is its "How to Debate Your Teacher (and Win!): Empowering Students to Have the Confidence to Defend their Beliefs in Classrooms and Universities." The opening lines argue that, "Today, teachers and 
professors all across the country are training young minds to believe that capitalism is immoral. It's up to you to stand up for what you believe in" (Turning Point USA, 2015a, foreword ). In all, the piece is offered without substantiation and relies heavily on emotional appeal and fear-mongering. Accordingly,

This booklet is designed to empower students to fight back against this progressive aggression in our schools. Turning Point USA has outlined a blueprint to deter the typical strategies used by teachers and professors; we have also provided tips to swing the narrative away from indoctrination toward a balanced classroom environment. Throughout this booklet we highlight real life success stories of students who stood up to their teachers and successfully prevented outward anti free enterprise aggression from occurring in their classrooms. We show you that it is possible to fight back and enlighten your fellow classmates to the truth about history, civics, and economics. (Turning Point USA, 2015a, foreword)

Arguing that public school K-12 teachers and college professors are radical leftists, TPUSA like so many other organizations that center fear mongering as a political strategy, argue that "everybody has that one crazy liberal professor that drives you absolutely insane. Whether they obsess over wealth distribution, bash capitalism, or try to paint the free market as the most awful economic system to ever exist, they are teaching liberalism rather than fact" (Turning Point USA, 2015a, p. 1). Contrary to avoiding the public sphere by way of homeschooling, for example, TPUSA hopes its followers attack, head on, the very things that drive some families away from public schools and public universities in favor of homeschooling and/or private education. It is worth noting that TPUSA is part of a growing network of conservative and neoconservative organizations that share ties with the school reform and school privatization agenda (Brewer \& Swain, 2020) including organizations such as Reason that often pushes false narratives about homeschooling (Tuccille, 2019).

Further, claims that capitalism is taught as a "greed-motivated economic system" in schools represents a misdirection or misunderstanding of the tenets of capitalism that quite literally center on self-interested individualism. Of the notable literature often cited by conservatives and republicans in their defense of capitalism and free-markets is the seminal work Atlas Shrugged by Ayn Rand (1957/1999) where individual self-interest and greed improve the lives of the individual and, in turn, society. If everyone is able to focus on bettering their own lives, sans influence and the burdens of government and collective society, then the individualism described in Rand's work (or, greed) is the driving factor in societal improvement. 


\section{A Brief History of Teacher Preparation}

Given the myriad early forms of schooling in the U.S., there was not much in the way of formalized teacher preparation or a process of teacher certification. As most early schools - overseen by local communities and towns - focused primarily on teaching the Bible (Fraser, 2014; Urban \& Wagoner, 2009), individuals who were seen to be moral, upstanding, and who possessed knowledge of the Bible were hired to teach. The formal requirements for maintaining a job as a teacher included, in some instances, less attention on being a 'good teacher' and more on being a 'good person' as evidenced by their being prohibited from riding in cars with men other than a father or brother and not being allowed to spend time in downtown ice-cream shops.

Among the most notable early forms of a more formalized preparation for teachers can be found in Catharine Beecher's Hartford Female Seminary where she sought to train women for work as teachers. And while Beecher's ideology was one that both celebrated the traditional role of woman-at-home, she also forged new understandings about the role of women outside of the home - dominantly as school teachers (Urban \& Wagoner, 2009) - as she advocated for the United States to open the types of "normal" schools that trained teachers in the same way that France and Prussia (Prussia's form of schooling becoming the model upon which U.S. schools ultimately were modeled after) trained teachers (Beecher, 1835). Normal schools would, in time, become the modern colleges of education that oversaw teacher preparation. To this day, traditional colleges of education and "traditionally certified teachers" are the mainstay of teacher preparation in the U.S. And while every college of education differs in its approach, they have certainly evolved from Beecher's regulations and oversight that was grounded in her theology, to oversight from the Council for the Accreditation of Educator Preparation (CAEP) that now regulates almost all traditional forms of teacher preparation. CAEP is a recent consolidation of the National Council for the Accreditation of Teacher Education (NCATE) that began in 1954 with the goal of "rais[ing] the quality of preparation [of teachers]" and the Teacher Education Accreditation Council (TEAC) founded in 1997 to ensure evidence-based qualifications (Council for the Accreditation of Educator Preparation, n.d.).

Juxtaposed to the traditionally certified teacher and colleges of education are those teachers who enter the profession by way of an alternative certification program/organization that circumvents the years of coursework, practicum experience, and in many cases, the pedagogical tenants of teacher preparation associated with colleges of education. The term "alternative" in the phrase alternative teacher preparation aptly situates teacher preparation 
within the recent historical context of housing teacher preparation within colleges of education. On the face of it, alternative certification programs operate under the auspices of: (1) injecting competition into the "monopoly" of teacher preparation historically held by state universities; and/or (2) under the assertion and façade that teacher preparation can be expedited and that extensive training in both methodology and practicum practice (e.g., student teaching) is thus not a necessary component of sufficient teacher preparation. Additionally, alternative certification processes and organizations have received increasing support for expansion given the purported difficulty of staffing teachers in "hard-to-staff" schools - often urban schools that serve predominately non-White and non-affluent students. The combination of those assumptions work to reify the existence of alternative certification programs as a necessity to combat burdensome government oversight (like CAEP) and expenses at the state level (e.g., funding for colleges of education) in addition to offering individuals who aspire to be teachers a faster - and assuredly cheaper - entry into the field while seemingly serving as the best solution to a problem that traditional colleges of education have not been able to solve. However, as noted by some (Roth \& Swail, 2000), since the advent of teacher colleges (e.g., traditional certification) did not occur until the late nineteenth and early twentieth century, that alternative certification routes (in this definition, alternative meaning less formalized as is now the case of the traditional route) were actually the basis of teacher credentialing. That is, since local communities were responsible for hiring teachers and there existed no colleges of education - or normal schools at the time - the credentialing process was not formalized and was entirely up to local leaders to determine what constituted a 'qualified' teacher. Again, that determination was up to the discretion of community leaders and their evaluation of an individual's grasp on the Bible and other moral expectations.

Alternative certification programs have taken on many shapes and sizes. The most notable of nation-wide programs include Teach For America (TFA), the New Teacher Project (TNTP), and the Relay Graduate School of Education (formerly known as "Teacher U"). There are also city-specific programs like the New York City Teaching Fellows in addition to state-specific programs for alternative licensing. However, the latter state-based licensing programs tend to not recruit candidates; rather, they provide coursework often in partnership with a local university's college of education for individuals who are seeking employment as a teacher but do not have a traditional background in education. TNTP was founded in 1997 by TFA alumna Michelle Rhee and functions in similar ways to that of TFA. Though, an important branching off specific to TNTP has been the organization's production of original research that has 
argued that teacher unions are one of the main obstacles to education reform (Levin, Mulhern, \& Schunck, 2005). Recently TNTP produced a study that concluded that current forms of teacher professional development are inadequate and that professional development should be more specific towards helping teachers increase metrics (e.g., test scores) (The New Teacher Project, 2015). TNTP founder Rhee became the Chancellor of D.C. Public Schools in 2007 and resigned in 2010 following an election cycle and accusations of cheating. Following her resignation, Rhee established Students First, a lobbying organization that publishes state-based grading scale each year in addition to providing political and financial support for anti-union activities. With the help of Students Matter (an organization that is supported by Rhee and Students First), the high profile anti-teacher union case of Vegara $v$ California made national headlines as the decision of the Court found that teacher tenure laws were unconstitutional (Students Matter, 2014; "Vergara v. California," 2014).

Yet, as will be explored below, the phenomenon and practice of homeschooling eschews all parameters of a traditional or professional sense of what it means to be trained sufficiently to teach children.

\section{Who Is Capable of Teaching at Home?}

Certainly one of the most notable components of homeschooling is that a parent (or some combination of adults) is responsible for teaching one, and in many cases more than one, student at home. As a result, questions surrounding the qualifications of those who teach are a necessary component of the homeschooling discussion and debate. Again, this question aligns with the overarching consideration of the role, function, and limits of parental sovereignty and notions of the role and authority of the state to provide formal education. Weaving throughout considerations of who can, should, and ought to be allowed to teach (in any form of schooling whether it be public, private, or homeschooling) is the notion and understanding of expertise. Generally speaking, expertise comes with a significant level of regulation on who enters into a specific field of knowledge and practice. Parents naturally possess the right of parental sovereignty as a natural function of being a parent. This authority generally remains unquestioned and unchallenged apart from a violation of societal norms surrounding agreed upon limits of that sovereignty (e.g., neglect and abuse) where the state's responsibility and authority overrides parental sovereignty. While parents are the natural teachers of their children at home in terms of socialization, family culture, family beliefs, and oversee early physical development (e.g., crawling, walking, and speaking), 
the practice of homeschooling extends the understanding and boundaries of parental sovereignty to define parents as being qualified to provide and deliver educational curriculum. Said more plainly, some homeschooling advocates suggest that because a parent is the one who teaches a child how to tie her shoe, the parent is the natural-best person to teach the child organic chemistry (Bryant, 2020). What is interesting here is that crawling, walking, and speaking are often held up as examples of early educative lessons taught to children by their parents. And while it is true that parents assist children with these things, crawling and walking would occur naturally and speaking is developed through mimicking, listening, and practicing. Keeping in mind that notions of proper syntax are concepts created by professionals and many homeschooling parents themselves, learned proper grammar and speaking syntax from public schools and the professional teachers who staff them.

With that in mind, I want to point out here that I am, myself, a parent twice over. At the time of this writing, my daughter was 5 , nearly 6 , and my son was 4. My wife, their mother, and I did our best and aim to continue in those efforts that aid and assist our children in their natural and healthy development. We installed rubber foam around the raised fireplace hearth when our son started walking (we did not have this feature in the house we lived in when our daughter was learning to walk) so as to help prevent injuries as he did stumble and fall, as all children do when they learn to walk. At times, we chose to take our children outside so that they could learn to walk on more uneven surfaces such as the sidewalk that went around the circumference of our neighborhood block. The problem with walking on sidewalks - and later running on them as toddlers and kindergartners - is that falls often result in skinned knees. As caring parents, we showed our children how to put on bandages (often with whimsical cartoon characters that, apparently, helped soothe the pain) that would aid in the slowing of bleeding and prevention of infection. While she may not want to admit it - especially through the tears of a contemporary need for a bandage on a skinned knee - I'm quite sure that my daughter can adequately open and position a bandage on a scraped knee. With no doubt, this is something that we taught her as her parents and, in a way, as her educators. However, it would be beyond any reasonable explanation to suggest that either of us as parents are qualified, equipped, or adequately prepared to tend to a broken bone as a result of a harder fall. In fact, it would likely be reasonable to suggest that a claim that I, by virtue of being the parent, am qualified or more qualified than a medical professional to reset a bone, cast a leg, schedule and provide antibiotics if the break of the bone penetrates the surface of the skin would be akin to parental malfeasance or negligence. My teaching of how to apply a bandage is not sufficient or adequate experience necessary to 
address anything more medically serious than a minor scrape on a knee. It is not enough to know how to suture a larger wound. My knowledge and experience of putting antiseptic creams on a scratch is not sufficient or adequate experience to teach my child about biology or chemistry - even with the added aid of YouTube videos or mail-order curriculum. This is telling of how homeschooling families interpret the importance, profession, and rigor of education. That is, if they can teach small and early curriculum content to their children, then they are well suited to teach the more rigorous concepts and content later on. Not only is it problematic to claim that parents are well equipped or prepared to teach early childhood curriculum, but it is overtly clear that claims of qualifications to teach advanced curriculum are misguided.

In comparison, educator authority - as an extension of the state's authority is gained through a credentialing and legal process whereby individuals receive rigorous training that results in a license to teach. Such a credential conveys a level of expertise of subject matter, child development, pedagogy, and curriculum development. In short, homeschooling parents posit that the nature of being a parent provides the extended rationale for educating whereas the broader society posits that authority to teach must first be established by traditional training, credentialing, licensing, and broader understandings of entering a profession. Believing that parents are capable of teaching by nature of being a parent holds that authority and ability to teach curriculum is a natural byproduct of parenthood rather than earned expertise. Yet, this tension is not limited to questions of authority as many "homeschoolers are also wary of state intrusion into family life and generally are skeptical of the ability of bureaucracies and 'experts' to meet the task of child rearing" This dichotomy undermines traditional understandings of expertise and a profession as both are surrounded by specialized knowledge held by "people who have mastered particular skills or bodies of knowledge and who practice those skills or use that knowledge as their main occupation in life" (Nichols, 2017, p. 29) being a prerequisite for qualification as opposed to qualification by individual fiat.

Central to the belief that anyone can teach and the American adage of "those who can, do and those who can't, teach" is the assumption that teaching and education is not in and of itself a profession, rather, a technocratic skill that can be easily learned or exist without intensive and specific training. Howsam et al. (1976, pp. 15-16) provide a useful overview of the characteristics of a profession as:

1. Professions are occupationally related social institutions established and maintained as a means of providing essential services to the individual and the society; 
2. Each profession is concerned with an identified area of need or function (e.g., maintenance of physical and emotional health, preservation of rights and freedom, enhancing the opportunity to learn);

3. The profession collectively, and the professional individually, possesses a body of knowledge and a repertoire of behaviors and skills (professional culture) needed in the practice of the profession; such knowledge, behavior, and skills normally are not possessed by the nonprofessional;

4. The members of the profession are involved in decision making in the service of the client, the decisions being made in accordance with the most valid knowledge available, against a background of principals and theories, and within the context of possible impact on other related conditions or decisions;

5. The profession is based on one or more undergirding disciplines from which it draws basic insights and upon which it builds its own applied knowledge and skills

6. The profession is organized into one or more professional associations which, within broad limits of social accountability, are granted autonomy in control of the actual work of the profession and the conditions which surround it (admissions, educational standards, examination and licensing, career line, ethical and performance standards, professional discipline).

7. The profession has agreed-upon performance standards for admission to the profession and for continuance within it

8. Preparation for and induction to the profession is provided through a protracted preparation program, usually in a professional school on a college or university campus;

9. There is a high level of public trust and confidence in the profession and in individual practitioners, based upon the profession's demonstrated capacity to provide service markedly beyond that which would otherwise be available;

10. Individual practitioners are characterized by a strong service motivation and lifetime commitment to competence;

11. Authority to practice in any individual case derives from the client or the employing organization; accountability for the competence of professional practice within the particular case is to the profession itself;

12. There is relative freedom from direct on-the-job supervision and from direct public evaluation of the individual practitioner. The professional accepts responsibility in the name of his or her profession and is accountable through his or her profession to the society. 
While the profession of teaching is not without its contemporary barriers to realizing, in full, the above characteristics of a profession (Brewer \& Cody, 2014; Goldstein, 2014; Ravitch, 2010, 2013)

Every society has certain functions to be performed if life within it is to be sustained and if the quality of life is to be maintained or improved. Societies differ, however, in the way they organize to provide for performance of these functions. Simple societies diffuse the functions over populations. Complex societies, on the other hand, create work specialization and invent institutions and organizations to facilitate delivery and improvement of services. (Howsam et al., 1976, p. 14)

They go on to suggest that complex modern societies have necessitated the creation of five occupational categories: (1) professional; (2) semiprofessional; (3) paraprofessional; (4) skilled; and (5) unskilled trade.

Each of these represents service to others, made necessary by the reality that few if any people possess the knowledge and skills needed or the inclination to be self-sufficient in meeting their own needs. Thus, the difference between levels of occupations is not in the element of service, but in the nature of the service. Some needs are so fundamental that failure to meet them seriously interferes with the quality of life or with life itself. Professions customarily involve this kind of service. (Howsam et al., 1976, p. 14)

With this understanding in mind, we must ask ourselves if we consider the education and socialization of future generations of our society as fundamentally connected to a continued quality of life and the perpetuation of life itself. In a traditional sense, Horace Mann and, to a lesser extent, Thomas Jefferson understood that free and public education, compulsory up to a certain age, was the fundamental cornerstone to the survival of our nation and democracy. Thus, if we consider schooling and education as the bedrock of our democracy in our complex society, the perspective of Howsam et al. would require that education be an enterprise led by professionals and not treated as either a characteristic of a simple society or an endeavor not associated with the perpetuation of a society's quality of life - or the life of the society itself. In understanding the need for professional educators, the faith and trust in the ability to educate is not situated with an individual but rather within the broader institution of education that is "responsible for insuring that service 
to the client is competent within the limits of the existing art or science...the profession is the source of that confidence and assurance" (Howsam et al., 1976, p. 15).

There are 29 states that require a parent provide an annual notice that their child(ren) will be homeschooled for the upcoming school year - a constant documentation process in response to national compulsory schooling laws while there are ten states that require only a one-time notice and 11 states that require no notice be given (CRHE, n.d.-a).

The majority of states do not require a homeschooling parent to have, themselves, any formal level of education prior to assuming the role of educator within the home (Huseman, 2015). That is, there is no requirement of either a high school diploma or college degree. In short, a homeschooling parent could, themselves, have completed no more than the $5^{\text {th }}$ grade, for example, and charge themselves with teaching K-12 (including advanced subjects experienced in high school). Those 38 states are:

$\begin{array}{lll}\text { - Alabama } & - \text { Kentucky } & - \text { New Jersey } \\ \text { - Alaska } & - \text { Louisiana } & - \text { New York } \\ \text { - Arizona } & - \text { Maine } & - \text { Oklahoma } \\ \text { - Arkansas } & - \text { Maryland } & - \text { Oregon } \\ \text { - Colorado } & - \text { Massachusetts } & - \text { Rhode Island } \\ \text { - Connecticut } & - \text { Michigan } & - \text { South Carolina } \\ \text { - Delaware } & - \text { Minnesota } & - \text { Tennessee } \\ \text { - Florida } & - \text { Mississippi } & - \text { Texas } \\ \text { - Hawaii } & - \text { Missouri } & - \text { Utah } \\ \text { - Idaho } & - \text { Montana } & - \text { Vermont } \\ \text { - Illinois } & - \text { Nebraska } & - \text { Wisconsin } \\ \text { - Indiana } & - \text { Nevada } & - \text { Wyoming } \\ \text { - Iowa } & - \text { New Hampshire } & \end{array}$

And there are 2 states (California and Kansas) that require a homeschooling parent be able to show that they are "capable" of teaching yet, as ProPublica points out, there are no laws within those states as to qualify what constitutes capability and "officials are not allowed to exercise discretion" (Huseman, 2015).

There are 9 states that only require that a homeschooling parent hold a high school diploma, yet, 4 of those states (District of Columba, Ohio, North Dakota, and Virginia), allow that requirement to be waived though evidence that a parent can prove their ability to teach or through a temporary monitoring of some form before the requirement is waived (Huseman, 2015). Those states requiring only a high school diploma are: 
- District of Columbia

- Georgia

- New Mexico

- North Carolina

- North Dakota

- Ohio

- Pennsylvania

- South Dakota

- Virginia

The determination on whether or not a parent is educationally qualified to teach in West Virginia is left to the discretion of a local superintendent. Parents wishing to be the lead educator in the lives of their child(ren) in Washington must satisfy one of four requirements: (1) be supervised by a certified person; (2) achieve a minimum number of college credits (e.g., hold a high school diploma and have completed "some" college); (3) have taken a course in how to homeschool; or, (4) been deemed qualified by their local school board (Huseman, 2015). So, in short, the most rigorous educational attainment standards for a parent to be the primary/lead educator in the lives of children by way of a homeschool is having an educational experience no greater than what they may themselves be teaching. This reality stands in stark contrast to what is actually a rigorous training and credentialing process that public school teachers undergo prior to being charged with leading the educational experiences, learning, and assessments of students. Educators teaching in public K-12 systems must at least have a bachelor's degree from an accredited university as, generally speaking, the standard practice in regulated education is that an educator must hold one degree higher than the level in which she is teaching with the notable exception of the doctoral level as it is a terminal degree:

\begin{tabular}{ll} 
Teaching level & Required degree level \\
\hline K-12 & Bachelor's \\
Bachelor's & Masters \\
Masters & Doctorate
\end{tabular}

More to the point, the requirements to teach as an educator in a public K-12 school require that, prior to being hired, a teaching candidate complete the course of study through a college of education. In addition to detailed and extensive content-area course training, a teaching candidate will, through their 
traditional training, receive and complete training in a myriad of pedagogical and developmental courses that include:

- Critical and Contemporary Issues in Education (history of education, educational policy, etc.)

- Sociocultural Diversity

- Educational Psychology (how students learn, develop, learning theories, assessment theories, etc.)

- Teaching Reading in a Content Area

- Curriculum \& Pedagogy

- Classroom Data Analysis

- Educational Assessment

- Coursework on Teaching students with Exceptionalities

- Classroom Management

- Content-specific Methods coursework

Further, public school teacher candidates must also complete hundreds of hours of observations, mini-lessons, and either a half-year or full-year student internship where the candidate gradually takes over classroom responsibilities under the supervision of a fully licensed veteran teacher. This entire practicum experience is assessed by not only the local educators within the school where the student teaching experience is occurring but also under the supervision of a university-based professor of education and ultimately assessed in many states using the edTPA educator assessment and some state-level credentialing exam (e.g., the Praxis exam or other varied state versions of the test). While assessment instruments such as edTPA are wholly not without their problems (Carter \& Lochte, 2017; Kumashiro, 2015; Mathis, 2013; Whitaker \& Burns, 2019), the approach marks a stark difference in accountability when approving individuals with the steep task of educating the next generation.

Yet, homeschooling does not interpret education as a profession and, simultaneously, understands the act of teaching as an endeavor that does not require extensive training prior to taking on the responsibility of teaching. At a session designed for parents who were considering or in the early stages of beginning to homeschool at the Southeast Homeschooling Expo, one of the opening speakers explored the likelihood that those in the room would certainly encounter push-back and objections to their decision to homeschool by both their family and friends. The speaker noted that among the top objections that they would encounter are people questioning their ability to provide an education for children - particularly given that there are not stringent educational or credentialing requirements. Further, the speaker noted that there would be times where the parent who is homeschooling may very well question their own ability and qualifications to be the sole educator for their children. To both these external 
and internal objections, the speaker stated that, "when people ask you what makes you qualified to teach your children [algebra, chemistry, reading, history, etc.], tell them that you're the most qualified person on the planet because you gave birth to them." Again, this disposition towards understanding teaching not as a profession but as something that can be done without training and, in this case, is best done as a result of birthing, draws back into focus the overarching disdain for expertise within the homeschooling community. Along the lines explored at the opening of this chapter related to the argument that a parent, by fiat of being a parent, is the most suited to teach their children, homeschooling advocates push this logic often. A notable homeschool blogger claims that, "Rest assured that, as a parent, you are the best teacher your children could have. No one knows your children better than you" (Linsenbach, 2010, p. 18). Imagine, for a moment, that the word "teacher" were replaced in the sentence above and whether or not the rationale or justification would still stand. For example, if "teacher" were replaced with, say, "doctor," or "lawyer," or "nutritionist," etc., the sentence would seemingly fall apart under the justification that because one is a parent, one is qualified. Again, similar to the claims mentioned above about a natural qualification due to birthing a child, Linsenbach suggests that, "You might be concerned that you 'don't know how to teach.' But you have already been and continue to be your child's teacher. You are the one who cared for your child as a baby, and you are the one who taught your baby to walk, to talk, to eat the right foods, to cross a street safely, to treat others kindly, and much more" (Linsenbach, 2010, pp. 18-19). Linsenbach doubles down on many of these claims that are worth including at length here:

Yes, you can homeschool your child! You needn't be a professional teacher to educate your child at home. Children are natural learners, and parents are natural teachers. You've seen your child learn and grow with your guidance and love since the day your son or daughter was born. Homeschooling is similar to parenting your child and just as rewarding! (Linsenbach, 2010, p. 15)

From the earliest days, a child's education took place inside the home. Children learned from parents, from a large extended family, and from everyday life. They learned to read books on their own or from older siblings. They practiced their alphabet, penmanship, and math problems on slate with a slate pencil. Families made sure their children learned important life skills; reading, writing, and math skills; and socialization skills. They taught their children morals and values, proper manners and etiquette, how to get along with others, and how to respect their elders. (Linsenbach, 2010, p. 16) 
As the Industrial Revolution swept the country, school transportation improved and so did attendance at public schools. However, in the 196os and 1970s, some families, disappointed with the public school system, began teaching their children at home. Early homeschool pioneers and advocates broke new ground in the homeschool territory. Family-centered education began moving to the forefront of society again. (Linsenbach, 2010, p. 17)

What is not mentioned here, however, is that the 196os and 1970s were an era of racial integration within public schools and, as Linsenbach eludes to, school transportation using busses were employed under bussing policies specifically designed to help integrate schools - particularly in areas that were hesitant to federal integration rulings and laws. While there are little overt nods towards choosing to homeschool out of racist intent, many of the foundational policies supporting school choice (e.g., homeschooling expansion, school vouchers, and charter schools) have included a desire to avoid racial integration (Brewer \& Potterton, 202O; MacLean, 2017).

Much of the central theme with the belief that a parent is the best teacher for their child because they know their children better than any other adult seems to be a persistent and common theme in other areas of life normally understood to be best served by professionals rather than novices. For example, the past decade has seen a massive increase in the anti-vaccine movement for a myriad of reasons. Chiefly among them is the false-belief that vaccines cause autism. That is, many parents believe that there is a causal relationship between vaccines (specifically the Measles, Mumps, and Rubella - or MMR vaccine) and the onset/manifestation of autism. Failing to understand that correlation does not imply causation, the myth of the link between vaccinations and autism became popularized by a, now redacted, peer-reviewed study published in the top medical journal The Lancet. While the lead author of the study has since lost his medical license and the study has been thoroughly debunked by subsequent studies, the damage inflicted remains. And while the vast majority of American citizens do not read peer-reviewed articles (namely because they are behind paywalls and employ a significant level of professional jargon), the myth of a link between vaccines and autism has been promoted and sustained by a slew of celebrities like Jenny McCarthy and Jim Carrey and if there is anything to be said about American culture, the typical American is infatuated by celebrity. And while not all anti-vax parents arrive at such a disposition as a direct result of celebrity influence, it seems that most arrive at such conclusions by way of conducting internet "research." While the internet has been a boon for information and even fostering the rise of democracies 
as was the case of the Arab Spring, the internet is equally full of misinformation that often reinforces echo chambers and confirmation biases across every conceivable topic of consideration - vaccines, politics, religion, and homeschooling. A random sampling of the comment sections on pseudo-medical blogs or social media like Facebook and Twitter will likely return dozens of comments of defensive anti-vaxxers (as they are known) either suggesting on the front end that they have "done their research" and/or will attempt to end a discussion with some iteration of, "well, you just need to do your own research like I did." Internet "research," again, often results in the generation of echo chambers and biases but also erodes at the notion of expertise. Additionally, the connotation of "research" and the access of information (particularly the ability to access information that results in confirmation bias) establishes the belief that any and all information is of equal value. As a result, it is often the case that people feel empowered to argue with experts - say, a physician or a representative of the Centers for Disease Control and Prevention - in a way that elevates a degree from the "University of Google" with that of actual expert knowledge. In fact, "there is no way to enlighten people who believe they've gained a decade's worth of knowledge because they've spent a morning with a search engine. Few words in a discussion with a lay-person can make an expert's heart sink like hearing 'I've done some research'” (Nichols, 2017, p. 120). As Nichols goes on to suggest, "Americans now think of democracy as a state of actual equality, in which every opinion is as good as any other on almost any subject under the sun" (Nichols, 2017, p. 232).

This false sense of expertise and possession of "knowledge" that gives the façade of expert knowledge is part-and-parcel of the landscape that reinforces the belief that a biological parent who has "found some online resources" is just as qualified, if not more qualified, than a professional educator who has completed a rigorous course of study and credentialing process.

My point here is not to draw parallels to what are seemingly disparate forms of anti-intellectualism, anti-expertise, or anti-professionalism, in an attempt to make one group guilty by association. However, the point here is that vaccinations and the growing trend of parents to assert parental sovereignty and online "research" over the qualifications of actual experts and what is to be understood as a societal commitment to maintaining itself. Further, there is an overt connection between the homeschooling movement and the anti-vaccine movement as the HSLDA specifically rates states on their friendliness to homeschoolers with a category on whether or not the state still requires children to be vaccinated (HSLDA, n.d.; Huseman, 2015). Thus, the deregulation of schooling (by way of homeschooling) and the deregulation of vaccinations (allowing parents to opt-out either as public school attendees or, in this case, 
homeschoolers) go hand-in-hand with what can be best understood as a belief that parents are the most suitable, knowledgeable, and best providers of education and medical intervention in the lives of their children. Some of this, it would seem, stems from the broader anti-intellectual movement but it also stems from a political philosophy more closely aligned with libertarianism and notions of rugged individualism. In fact, Bethany Mandel, a homeschooling parent, penned an Op-Ed in the New York Times pointing out that the anti-vax movement and the homeschooling movement are aligned as a "go-against-thegrain attitude."

Yet, while Mandel makes a strong argument for the connections between the anti-vax movement and homeschooling, she failed to see the irony of wanting to push back against the anti-professionalism of the anti-vax environment within the anti-professionalism of the homeschooling movement which, in the same column, lauded. On the one hand, Mandel praises medical expertise, the importance of herd immunity, and the ability of the State to step in and act on behalf of the larger society by superseding parental sovereignty. What is not acknowledged in Mandel's arguments, and others like it, is that as society has become more complex and thus warranted a professional approach to education - as discussed above - the maintenance of a complex society demands that we establish educational professionals, a herd-immunity when it comes to knowledge and education, and ultimately the ability of the State (the formal society) to supersede notions of parental sovereignty. That is, following the metaphor of how we understand herd-immunity as a mechanism through which immunity among a majority of the population naturally protects not only itself but it protects the spread of disease by not providing willful hosts - thus not only protecting the most vulnerable individuals in the herd but the herd as a whole. It seems to follow that notions of compulsory public education as espoused by Mann and Jefferson sought to provide the same level of herd-immunity when it came to facts, knowledge, training, and skills. For a society to survive a preventable outbreak of a communicable disease, herd-immunity is a necessary component. Equally, for society to survive communicable ignorance (both in the sense of preventing the spread of true knowledge as well as the suppression of false myths - say, that vaccines cause autism), there must be a standard inoculation provided to society if it is to survive itself. Otherwise, when education is approached as everyone for themselves, not only does actual truth become siloed in a bubble, it creates the capacity for rumor, fear, and conspiracy to roam freely (think, women as witches during the Salem witch trials) that results in rule by paranoia.

In continuing with the parallel of vaccinations, if you will permit, it may be of use to think about the dosage and schedule of dosage as a metaphor for 
how education can serve as the inoculation against society's downfall. In the same way that many vaccines are scheduled to be delivered in small doses over time, much of our general approach to school curriculum is done in the same manner. And while there is much to be discussed about some of the downfalls of piecemeal instruction - notably a discussion beyond the scope of this work - it is worthwhile to compare and contrast the scope and sequence of content exposure between a typical traditional public school and what is recommended for homeschooling instruction. A speaker at the Southeast Homeschool Expo suggested that, "students K-6 should only be spending 30-6o minutes per day doing 'school' but that's more than what they get in public schools because teachers have to spend most of their time breaking up fights and settling students down" (Henn, 2019). Similarly, Linsenbach suggests that:

The actual time required to focus on core skills (language arts, reading, social studies, math, and science) can be broken down per age group as follows:

- Preschool and Kindergarten: 30 to 60 minutes per day

- Elementary-school ages: 6o to go minutes per day

- Middle-school ages: 1.5 to 3 hours per day

- High-school ages: 2 to 4 hours per day. (Linsenbach, 2010, p. 23)

By comparison, public school schedules generally practice the following:

- Preschool and kindergarten: Academic content typically focuses on reading and writing and other soft skills such as letter recognition, calendar literacy, that exceeds 30-6o minutes per day while a significant portion is dedicated to structured and unstructured play and socialization.

- Elementary-school ages: Skews heavily towards reading, writing, and mathematics and can range from 1.5 and 2 hours each day in reading and writing and another 1.5 hours in math with a ranging amount of time dedicated to other content subjects such as social studies, science, and the arts while providing structured and unstructured opportunities for socialization.

- Middle-school ages: 55-65 minutes per content/subject, generally totaling 6 hours per day spent in content-knowledge courses with additional time spent in extracurricular and social activities.

- High-school ages: 55-65 minutes per content/subject, generally totaling 6 hours per day spent in content-knowledge courses with additional time spent in extracurricular and social activities.

Assuming that children attending public schools are in a learning environment for 7 hours per day for a standard school year of 180 days, students attending public schools from Kindergarten to 12th grade would amass 1,260 hours per 
school year or 16,380 over the duration of 13 years of school. Following the suggested time for homeschooling as explicated above, a student homeschooled from Kindergarten to 12th grade would amass between 3,240 and 6,030 across the same 13 years. On the conservative end, that would mean that a homeschooled student spends only $20 \%$ of the time that a public school student does focused on academic work. To be sure, not every single moment of every single minute in a public school academic classroom is focused (intentionally or not) on learning but so too is it likely that budgeted time at home for academic work can be distracted by the student or external forces.

Academic time aside, homeschooling families often see their "incentive, apparently, [as] a mix of religious conviction and a suspicion that the public schools were not adequately doing their job" (Stevens, 2001, p. 3) or that the needs of children who are homeschooled are "too distinctive to be handed over to strangers" (Stevens, 2001, p. 4). No matter the rationale or justification (or combination of them), the fundamental presupposition of homeschooling is that public schools not sufficient educative environments or represent a negative to be avoided.

In his seminal text, Mitchell Stevens documents that, "Homeschoolers also are wary of state intrusion into family life and generally are skeptical of the ability of bureaucracies and 'experts' to meet the task of child rearing" (Stevens, 2001, p. 5). Additionally, Stevens (2001) notes that,

Schools are bad because they do not treat children as individuals. Children have problems in school because schools do not serve their individual needs. Schools are like factories, but children are not like machines. Children are unique, but schools do not honor that uniqueness. These contrasts, repeated by many speakers in many kinds of texts and read by home schoolers time and again, forge a view of children as unique persons that conventional schools can never adequately serve. Once inside this literature, parents are encouraged by its litany of claims to lend the uniqueness of their children great importance. Distinctiveness is rendered too significant and too fragile to be entrusted to others. (p. 43)

In other ways, the rise of homeschooling can, perhaps, be understood as a response to the increasing burden placed on students in public schools that have exchanged education for schooling. That is, as high-stakes testing accountability has decidedly demoralized the education climate in schools in its attempt to standardize learning and outcomes, alternative approaches to education that embrace, at its core, a more humanizing disposition towards children is understandable. 
The issue, however, is that while the abandonment of the public sphere in favor of the individual child (even as a good faith exercise of what is best for the humanity of children) is a form of school choice that is explicitly not available to all students. Given the vast amount of financial resources it often requires to homeschool (namely the forgoing of a parental salary so that a parent can remain home with the children), the relatively more affluent families that are able to opt-out of what they see as a dehumanizing public school process create, by default, a concentration of less fortunate students in the public school who are not able to provide the means of an individualized education at home. The very nature of public education and common schools was devised explicitly because the majority of children in the United States could not afford private home tutors (Urban \& Wagoner, 2009). To the ends that it is correct to understand the dehumanizing tendencies of public schools as a justification for seceding away from the public sphere, the practice exacerbates and highlights the growing financial disparities in American society and likely reinforces some of the more negative experiences within public schools as families who have a considerable amount of social and cultural capital could otherwise leverage to improve public schools rather than abandoning them all together. In their abandonment of public education to focus on the individualistic needs of their own children, communities suffer the long-term impacts of a public school system that is devoid of involvement from families that could help improve the schools and, as a result, ensure the short and long term efficacy of their own community and the nation with an understanding of the role that public education plays at both the local and national level.

Historically, the United States economy afforded the opportunity for White mothers to be stay-at-home parents. Our pop culture artifacts of television shows, movies, and songs often present the mother as homemaker in shows such as Leave it to Beaver and MadMen. And while this single-parent income of the nostalgic 5 os was largely not an opportunity enjoyed by non-White families - and to some extent, not actually as pervasive as nostalgic myths might have us believe (Coontz, 1992) - the changing economic conditions over the past four decades have certainly squeezed more American family's home economies in such a way that most households now rely on two incomes.

\section{References}

A2Z Homeschooling. (n.d.). HSLDA and gun free school zone act. Retrieved February 18, 2020, from https://a2zhomeschooling.com/main_articles/hslda_gun_free_school_ zone_act/ 
Baidi, I. (2019). The role of parents' interests and attitudes in motivating them to homeschool their children. Journal of Social Studies Education Research, 10(1), 156-177.

Beecher, C. (1835). An essay on the education offemale teachers. Van Nostrand \& Dwight.

Berliner, D. C., \& Biddle, B. J. (1995). The manufactured crisis: Myths, fraud, and the attack on America's public schools. Addison-Wesley.

Berliner, D. C., \& Glass, G. V. (2014). 50 myths and lies that threaten America's public schools: The real crisis in education. Teachers College Press.

Brewer, T. J., \& Cody, A. (2014). Teach for America: The neoliberal alternative to teacher professionalism. In J. A. Gorlewski, B. Porfilio, D. A. Gorlewski, \& J. Hopkins (Eds.), Effective or wise? Teaching and the meaning of professional dispositions in education (pp. 77-94). Peter Lang.

Brewer, T. J., \& Lubienski, C. (2017). Homeschooling in the United States: Examining the rationales for individualizing education. Pro-Posições, 28(2), 21-38.

Brewer, T. J., \& Potterton, A. U. (2020). How market forces and erosion of education as a public good drive equity gaps wider. In M. Soskil (Ed.), Flip the system us: How teachers can transform education and strengthen American democracy (pp. 82-96). Routledge.

Brewer, T. J., \& Swain, A. (2020). Operationalizing toxic ideology: How radical rightwing campus organizations undermine democratic engagement In K. deMarrais (Ed.), Conservative philanthropies \& organizations shaping U.S. educational policy \& practice (pp. 201-222). Myers Education Press.

Bryant, J. (2020). Homeschooling movement sees opportunity during health calamity. Retrieved April 7, 2020, from https://www.laprogressive.com/homeschoolingmovement/

Bushak, L. (2014). The 'STD hotspots' of America: Which states are most affected by chlamydia, gonorrhea, and aids? Retrieved February 13, 2020, from

https://www.medicaldaily.com/std-hotspots-america-which-states-are-mostaffected-chlamydia-gonorrhea-and-aids-270761

Carter, J. H., \& Lochte, H. A. (Eds.). (2017). Teacher performance assessment and accountability reforms: The impacts of edtpa on teaching and schools. Palgrave Macmillian.

CDC. (2017). Over half of U.S. Teens have had sexual intercourse by age 18, new report shows. Retrieved February 14, 2020, from https://www.cdc.gov/nchs/pressroom/ nchs_press_releases/2017/201706_NSFG.htm

CDC. (n.d.). Reproductive health: Teen pregnancy. Retrieved February 13, 2020, from https://www.cdc.gov/teenpregnancy/about/index.htm

Children, H. s. I. (n.d.). Home. Retrieved February 17, 2020, from https://hsinvisiblechildren.org

Children's Hospital of Philadephia Researach Institute. (n.d.). Gun violence: Facts and statistics. Retrieved February 18, 2020, from https://injury.research.chop.edu/ violence-prevention-initiative/types-violence-involving-youth/gun-violence/gunviolence-facts-and\#.XkwQny3 $\mathrm{MzOQ}$ 
Coontz, S. (1992). The way we never were: American families and the nostalgia trap. Basic Books.

Council for the Accreditation of Educator Preparation. (n.d.). History. Retrieved March 23, 2015, from http://caepnet.org/about/history/

CRHE. (n.d.-a). Homeschool notification. Retrieved March 27, 2020, from https://responsiblehomeschooling.org/policy-issues/current-policy/notification/

CRHE. (n.d.-b). Search: Abuse. Retrieved February 17, 2020, from https://responsiblehomeschooling.org/?s=abuse\&submit=Go

Cui, J., \& Hanson, R. (2019). Homeschooling in the United States: Results from the 2012 and 2016 parent and family involvement survey (PFI-NHES: 2012 and 2016). National Center for Education Statistics. Retrieved from https://nces.ed.gov/pubs2020/2020001.pdf

Dahlberg, L. L., Ikeda, R. M., \& Kresnow, M. J. (2004). Guns in the home and risk of a violent death in the home: Findings from a national study. American Journal of Epidemiology, $160(10)$, 929-936.

deMarrais, K., Brewer, T. J., Atkinson, J. C., Herron, B., \& Lewis, J. (2019). Philanthropy, hidden strategy, and collective resistance: A primer for concerned educators. Myers Education Press.

Fraser, J. (2014). The school in the United States: A documented history. Routledge.

Goldstein, D. (2014). The teacher wars: A history of America's most embattled profession. Doubleday.

Grady-Pawl, S. (2017). Linking religion and teen pregnancy: There's a map for that. Retrieved Februaray 13, 2020, from https://thehumanist.com/commentary/linkingreligion-teen-pregnancy-theres-map

Henn, J. (2019). Take the mystery out of homeschooling. Paper presented at the Southeast Homeschool Expo, Atlanta, GA.

HHS. (n.d.). Trends in teen pregnancy and childbearing. Retrieved February 13, 2020, from https://www.hhs.gov/ash/oah/adolescent-development/reproductive-healthand-teen-pregnancy/teen-pregnancy-and-childbearing/trends/index.html

Howsam, R. B., Corrigan, D. C., Denemark, G. W., \& Nash, R. J. (1976). Educating a profession: Report of the bicentennial commission on education for the profession of teaching of the American association of college for teacher education. U.S. Department of Health, Education \& Welfare.

HSLDA. (n.d.). Homeschool laws in your state. Retrieved July 9, 2019, from https://hslda.org/content/laws/

Huseman, J. (2015). Homeschooling regulations by state. Retrieved July 9, 2019, from https://projects.propublica.org/graphics/homeschool

Jenna, B. (2009). Teen birth rates highest in most religious states. Retrieved February 13, 2020, from http://www.nbcnews.com/id/32884806/ns/health-childrens_health/t/ teen-birth-rates-highest-most-religious-states/\#.XkVaDy3 MzOQ

Klein, N. (2007). The shock doctrine: The rise of disaster capitalism. Picador. 
Kumashiro, K. (2012). Bad teacher! How blaming teachers distorts the bigger picture. Teachers College Press.

Kumashiro, K. (2015). Review of proposed 2015 federal teacher preparation regulations. National Education Policy Center. http://nepc.colorado.edu/thinktank/reviewproposed-teacher-preparation

Kunzman, R. (2012). Education, schooling, and children's rights: The complexity of homeschooling. Educational Theory, 62(1), 75-89.

Levin, J., Mulhern, J., \& Schunck, J. (2005). Unintended consequences: The case for reforming the staffing rules in urban teachers union contracts. The New Teacher Project.

Linsenbach, S. (2010). The everything guide to homeschooling: All you need too create the best curriculum and learning environment for your child. Adams Media.

Livingston, G., \& Thomas, D. (2019). Why is the teen birth rate falling? Retrieved February 13, 2020, from https://www.pewresearch.org/fact-tank/2019/o8/o2/why-is-theteen-birth-rate-falling/

Lubienski, C., \& Lubienski, S. (2014). The public school advantage: Why public schools outperform private schools. The University of Chicago Press.

MacLean, N. (2017). Democracy in chains: The deep history of the radical right's stealth plan for America. Penguin Books.

Mathis, W. (2013). Research-based options for education policymaking. National Education Policy Center. http://nepc.colorado.edu/publication/options

Metzl, J. M. (2019). Dying of whiteness: How the politics of racial resentment is killing America's heartland. Basic Books.

Nichols, T. (2017). The death of expertise: The campaign against established knowledge and why it matters. Oxford University Press.

Pollack, K. C. (2018). Report indicates a third of children removed from school to be homeschooled were involved in prior DCF abuse/neglect cases. Retrieved February 17, 2020, from https://responsiblehomeschooling.org/report-indicates-a-third-of-childrenremoved-from-school-to-be-homeschooled-were-involved-in-prior-dcf-abuseneglect-cases/

Prabhu, M. T. (2020). Child abuse reporting in georgia down by half since schools closed amid virus. Retrieved April 16, 2020, from https://www.ajc.com/news/state-regional-govt--politics/child-abuse-reporting-georgia-down-half-since-schoolsclosed-amid-virus/RKg3HzBy86Ai3QNq3jrZML/

Princiotta, D., Bielick, S., \& Chapman, C. (2006). Homeschooling in the United States: 2003: Statistical analysis report. National Center for Education Statistics. https://nces.ed.gov/pubs20o6/2006042.pdf

Rand, A. (1957/1999). Atlas shrugged. Penguin Random House.

Ravitch, D. (2010). The death and life of the great American school system: How testing and choice are undermining education. Basic Books. 
Ravitch, D. (2013). Reign of error: The hoax of the privatization movement and the danger to America's public schools. Knopf.

Ray, B. D. (2019). Research facts on homeschooling. Retrieved August 5, 2019, from https://www.nheri.org/research-facts-on-homeschooling/

Redford, J., Battle, D., Bielick, S., \& Grady, S. (2017). Homeschooling in the United States: 2012. National Center for Education Statistics. https://nces.ed.gov/pubs2o16/ 2016og6rev.pdf

Roth, D., \& Swail, W. S. (200o). Certification and teacher preparation in the United States. Educational Policy Institute.

Rozyla, L. (2015). Changes proposed to Florida's homeschool policies following girl's death. Retrieved November 12, 2015, from http://www.abcactionnews.com/news/localnews/changes-proposed-to-floridas-homeschool-policies-following-girls-death

Schillinger, D., Ray, B. D., Knapp, K., \& Newman, J. (n.d.). Homeschool vs. public school: The ultimate showdown. Retrieved February 17, 2020, from https://homeeducator.com/ homeschool-vs-public-school/

Stevens, M. L. (2001). Kingdom of children: Culture and controversy in the homeschooling movement. Princeton University Press.

Stewart, K. (2019). The power worshippers: Inside the dangerous rise of religious nationalism. Bloomsbury Publishing.

Students Matter. (2014). Vergara v. California case summary. Retrieved September 8, 2015, from http://studentsmatter.org/our-case/vergara-v-california-case-summary/

The New Teacher Project. (2015). The mirage: Confronting the hard truth about our quest for teacher development. The New Teacher Project.

Tuccille, J. D. (2019). Homeschooling produces better-educated, more-tolerant kids. Politicians hate that. Retrieved February 17, 2020, from https://reason.com/2019/o1/22/ homeschooling-produces-better-students/

Urban, W. J., \& Wagoner, J. L. (2009). American education: A history (4th ed.). Routledge. Vergara v. California (Superior Court of the State of California 2014).

Westover, T. (2018). Educated: A memoir. Random House.

Whitaker, W., \& Burns, J. (2019). Toward the end of teacher education? edTPA as the new guardian sentinel of teacher certification. In T. J. Brewer \& C. A. Lubienski (Eds.), Becoming a teacher in an age of reform: Global lessons for teacher preparation and the teaching profession (pp. 67-9o). Teacher's College Press. 